\title{
Return and
}

\section{reconstruction}

Report on a study of economic coping strategies among farmers in Farah Province, Afghanistan

July 1997

British Agencies

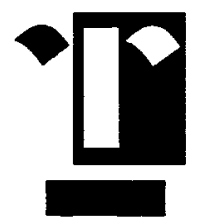

Afghanistan Group

the refugee council 


\section{Contents}

1. Introduction

2. Methodology

3. The context

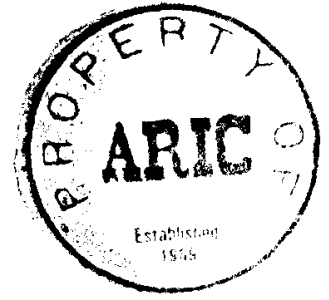

4. Findings

5. Conclusions

6. Recommendations 15

$\begin{array}{ll}\text { 7. Case studies } & 17\end{array}$

7.1 Mossaw Village, Pusht-e-Rud District 17

7.2 Zakin Village, Anar Dora District 21

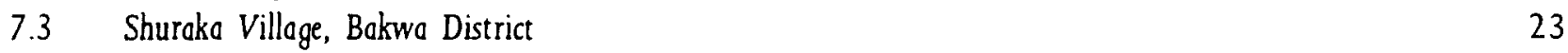

7.4 Dozbad Village, Pushtuku District, Qala-i-Koh 25

\begin{tabular}{ll}
7.5 & Chika Village, Shabiku District, Qala-i-Koh \\
\hline
\end{tabular}

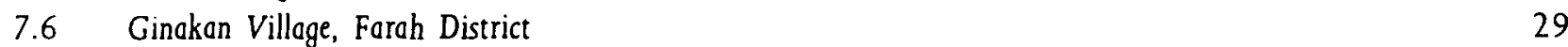

7.7 Kanesk Village, Bala Balouk District

$\begin{array}{lll}7.8 & \text { Raj Village, Pusht-e-Rud District } & 35\end{array}$

7.9 Denau Village, Khak-e-Safid District 39

8. Appendix 43

$\begin{array}{lll}\text { 9. } & \text { Maps } & 48\end{array}$ 
This report was prepared with financial assistance from the Commission of the European Communities. The views expressed are those of the NGO, and do not represent any official view of the Commission. 


\section{Acknowledgements}

We would like to record our appreciation of the considerable assistance provided by the three NGOs which facilitated this study, recorded in alphabetical order: Afghan Development Association, Coordination for Humanitarian Assistance and MERLIN. Each was generous with their time and provided senior members of their staff, together with high quality interpreters, drivers and vehicles. We are also very appreciative of the authority given by the Ministry of Foreign Affairs in Farah and by the representatives of the Taleban in the Districts visited. Finally, we would like to express our gratitude to the many village representatives who responded with patience to the numerous questions posed and accorded us hospitality.

Peter Marsden

Information Coordinator

British Agencies Afghanistan Group 


\section{Introduction}

The objective of the study was to establish, through interviews with farmers in Farah Province, including those who have returned after a period of displacement, the likelihood and feasability of durable socio-economic integration in the future.

The study was commissioned by the European Commission as part of its programme of funding for NGO projects and programmes for the self-sufficiency of refugees, repatriates and displaced persons.

There was, therefore, a particular interest in how successful the refugees who returned from Iran in 1992/93 had been in restoring the agricultural economy and in the potential of the economy to absorb those presently in Iran. 


\section{Methodology}

This is the third of three studies undertaken on the socio-economic impact of conflict on Afghan households, considering both those living in exile and those still in Afghanistan. The first study was undertaken in the summer of 1996 and considered the economic survival strategies of Afghan refugees in Iran and of Afghans returning to ruined villages in southern Afghanistan. The second study was conducted in December 1996 and sought to identify economic survival strategies among three groups of refugees in Pakistan.

For each of the studies, a semi-structured questionnaire approach has been adopted. The same basic questionnaire has been used for all the studies, with some small adaptations to suit the particular circumstances of each. For the present study, additional questions have been included to secure more detailed information relating to the agriculture sector and there has been a slightly greater emphasis on quantitative information.

This has, however, made the task more difficult because of the absence of written records and the consequent reliance on subjective estimates, even though, in many cases, there was much debate during the interviews as to what the appropriate figures might be. Caution should, therefore, be exercised in placing too much credence on the quantities given in the interviews. Land ownership figures are felt to be particularly problematic because of enormous variations between one village and another. These could sometimes be understood where, for example, low levels of land ownership could be related to poor growing conditions and evident poverty. It is also possible that there are some very large landowners in some districts - I was informed by one of the NGO staff of at least one - and this could affect the figures. It could also be the case that people have a very unclear picture of what the reality actually is. However, this has, historically, been a sensitive subject in Afghanistan and some respondents may have had good reasons for not giving an accurate picture.

A copy of the questionnaire is attached in the appendix.

The study was focused on areas where NGOs had operated or were planning programmes, so that the relationship between assistance and economic improvement could, to an extent, be identified. The three major NGOs working in the area, Afghan Development Association (ADA), Coordination for Humanitarian Assistance (CHA) and Medical Emergency Relief International (MERLIN) were therefore contacted to ask whether they would be willing to facilitate the study, through the provision of translators and vehicles. In each case, the NGOs extended a high degree of cooperation.

The target villages were selected at a meeting of all three agencies called on the first day in Farah. The researcher indicated that he wished to visit, over a nine day period, all the districts within reasonable travelling distance of Farah, the principle proviso being that it would be possible to make the return journey in one day. He was also concerned to visit the districts which had seen a significant return from Iran, based on the statistics collected by UNHCR at the border as returning refugees claimed their encashment packages. Fortunately, these coincided with the districts within reasonable travelling distance, with the significant exception of Shindand.

The agencies were then asked to denote the districts in which they were operational so that the 
relationship between their programmes and economic improvement could, to a degree, be identified. On this basis, it was agreed that the researcher would visit certain designated villages in the districts of Pusht-e-Rud, Anar Dara and Khak-e-Safid with CHA, in the districts of Pusht-e-Rud, Bala Balouk and Farah with ADA and in the districts of Bakwa, Pushtuku and Shabiku with MERLIN.

The authority of the Ministry of Foreign Affairs and of the Taleban representatives in the Districts was sought before the interviews were conducted.

In the target villages, the elders had, in some cases, been advised in advance of the request for an interview. In others, contact would be made on arrival with a key figure in the village who would send word for the other elders to attend. In either event, it was normal for a large group to have assembled within less than half an hour.

In most of the interviews, there would be contributions from a significant proportion of those present. However, in several interviews, including those in Bala Balouk, Raj Village and Farah, only one person spoke for the group.

The researcher had to be mindful of how long it was reasonable to retain people while seeking to obtain as much information as possible. Most interviews lasted for about two hours and only in one, that in Anar Dara, was impatience expressed, manifested by people starting to leave.

It was inevitable that, within the context of a socio-economic study of the agricultural economy of Farah, the impact of the NGO programmes concerned could not be considered in-depth. No attempt was, therefore, made to evaluate the programmes' effectiveness, only to indicate the contribution which they had made or could make to the economy. It is assumed, in this regard, that improved health has an economic impact.

In order to interpret the findings, it is important to note certain reference points referred to in the interviews. First, in making comparisons with the pre-war period, interviewees would refer either to the time of King Zahir Shah, who reigned up to 1973, or to that of President Daoud Khan, who held power from 1973 to 1978.

Some also referred to the period when the PDPA were in power prior to the Soviet invasion, i.e from April 1978 to December 1979, as the period of Taraki and Amin, the Presidents of that time.

It may be expected that the UNDP P.E.A.C.E programme, which will spend a significant amount of time in each District, will be able to provide a much more in-depth picture of the nature of the economy. It is, nonetheless, hoped that the present study will indicate the major patterns within the economy and prove of benefit to those considering programme and funding options. 


\section{The context}

Farah Province is situated in western Afghanistan, adjacent to the Iranian border. Herat Province, to the north, provides access to the major trading and cultural centre of Herat City. To the south, also bordering on Iran, is the highly inhospitable Province of Nimroz which links more closely with Iran than with the rest of Afghanistan. The main highway which stretches from Turkmenistan to Kandahar passes through eastern Farah, including Shindand, where the Soviet forces established a major air base. The provincial capital of the Province, Farah, is some distance to the west of the main highway.

Much of the area covered by the Province consists of a large flat plain interspersed with rocky outcrops. Only in the east does it encroach on the foothills of the Hindu Kush. It is dissected by two major rivers, the Farah Rud and the Harul Rud, and their tributaries. In the centre of the Province, on the opposite bank to Farah city, there is an area of relatively fertile land which has the potential to become much more productive if the supply of irrigation water could be increased. The outlying districts are surrounded by desert and have relatively small areas of cultivable land.

The Province receives heavy rain over a period during the winter. This can have a destructive impact if flood protection structures are not in place. However, it has the positive effect of creating a water table about six to ten metres below the surface. Individual farmers with the resources to buy water pumps have relatively easy access to water if they dig wells on their land.

UNDCP advised that poppies have been grown on a small scale in the Gulestan District in the eastern part of the Province and that some have also been cultivated elsewhere. The view was expressed that production had increased this year because of expectations that the Taleban might ban it next year. However, it was felt by UNDCP to be unlikely that production would, in any event, increase further, because of food requirements.

The smuggling of consumer goods across the Iranian border was said by a number of informants to be significant.

The Soviet period witnessed a significant exodus from Farah to Iran and many of the refugees established what were known as spontaneous settlements the length of the border. The Iranian Government estimated the population of these settlements to be 131,000. The Birjand settlements, which are mentioned in a number of the interviews, had a population of 56,000 .

When the Iranian Government, in December 1992, agreed a three-year repatriation programme with UNHCR, refugees were encouraged to return through a package of assistance given at the border. This consisted of one bag of wheat, $\$ 25$ per person and a sheet of tarpaulin per family.

A record was made at the border of the districts to which those claiming the package were returning. The numbers of people returning were as follows: Shindand: 27,218; Farah District: 20,535; Anar Dara: 7,726; Qala-e-Koh: 6,802; Khak-e-Safid: 6,050; Bakwa: 4,634; Bala Balouk: 3.019; Lash-e-Joveyn: 653; Purchaman: 443; Golestan:316; Farsi: 175 and Farahrud: none. It should be noted, in this regard, that many of those interviewed stated that signficant numbers had not been able to benefit from the package. The total of 77,571 may usefully be compared with the 
131,000 given by the Iranian Government as the population of the spontaneous settlements.

It was known before the study that the Iranian Government had bulldozed the spontaneous settlement to further encourage return. However, it was not known to what extent refugees had left voluntarily before this happened or whether the refugees had all returned to Afghanistan. It was thought that a significant proportion might have gone to the Iranian cities in search of work. One of the objectives of the study was to identify what the actual patterns of movement had been.

Similar records have been kept by UNHCR of those returning from Pakistan and qualifying for the repatriation assistance. The figures are as follows: Shindand: 19; Farah District: 1,665; Anar Dara: 33; Qala-e-Koh: 4; Khak-e-Safid: 122; Bakwa: 2,275; Bala Balouk: 3,369; Lash-e-Joveyn: 128; Purchaman: 3; Golestan: none; Farsi: 113 and Farahrud: 33. This total of 7,764 includes 5,644 who returned to Bala Balouk and Bakwa, which are adjacent to the main Herat-Kandahar highway, and, therefore, have relatively easy access to Pakistan.

The Province benefited relatively late from the assistance of humanitarian agencies. Thus, while agencies were able to begin working in Herat from 1992 onwards, responding to the security created by Ismail Khan, it took some time for Ismail Khan to achieve some degree of influence or control over the various party and traditional leaders in Farah. Only a few Afghan NGOs, including CHA, were in a position to operate under the conditions of relative insecurity which prevailed and they were able to undertake programmes as early as 1989. With the support of the World Food Programme, using food for work, and UNHCR, under its Quick Impact Programme, CHA has undertaken a number of construction or repair programmes to increase irrigation, improve roads and build schools, vocational training centres and community centres. In addition, with other sources of funding, it has sought to encourage diversification within agriculture by introducing kitchen and vegetable gardening. Improved seed has also been provided through multiplication programmes. Another NGO, VARA, has been engaged in road repair projects, also under contract to the UN.

Over the past couple of years, there has been an increase in agency activity. ADA has established a major programme to undertake large-scale irrigation projects and to further expand the network of schools throughout the Province. MERLIN has established clinics in all the Districts, with a strong focus on mother and child health. In each clinic, CHA organises a vaccination programme. The clinics operate a referral system to a nutrition unit and laboratory which MERLIN runs in the main hospital in Farah City. Medecins du Monde have successfully rehabilitated the hospital and assist in the organisation of medical services.

At the time of the study, UNDP was in the process of establishing its P.E.A.C.E. programme in Farah, aimed to target the most impoverished elements within the population through a community-based approach. Success will now be measured more on the basis of the effectiveness of the interaction with beneficiary structures in strengthening their capacity to achieve long-term change than on the technical outputs. The programme incorporates the UNDP OPS programme which has undertaken relatively sophisticated irrigation and water supply projects through an intensive consultation process with beneficiaries but without the strengthening of permanent community-based structures. The P.E.A.C.E. programme is targeting the Districts of Bakwa, Pusht-e-Rud and Khak-e-Safid among others.

Farah Province has been under Taleban control since September 1995, when the group also took Herat. Being predominantly Pushtun and espousing conservative rural values, the population have broadly accepted the advent of the Taleban. 


\section{Findings}

\section{The nature of the present economy}

It would appear that refugees returning from Iran have been able to re-establish themselves in substantial numbers, and with a reasonable degree of success, within the agricultural economy of Farah Province.

However, an important safety net is being provided through the availability of employment opportunities in Iran, particularly for young people.

This is not a desirable situation, given that those seeking to work in Iran have to enter the country illegally and are therefore at risk of arrest, imprisonment in detention centres and deportation. It was also clear from the interviews that the population at large do not regard this as desirable. Many expressed the hope that, if cultivation could be improved, it would prove unnecessary for the young people to work in Iran.

It was interesting to compare the findings in this study with those of the study undertaken in July 1996 in Iran. The latter study had indicated that young people were mainly working on building sites, in brick kilns or on cement-block making sites. In each case, they were provided with accommodation on site and, in return for extremely low wages, had reasonable guarantees of continued employment for months at a time. This was unlike the situation of men with families who were forced to look for work on a daily basis out of concern not to leave their families unprotected. Some of the young men interview'ed had been given documentation and were clearly known to the authorities.

The interviews in Iran also gave a mixed picture of the effectiveness of arrangements to send remittances back to Afghanistan. There were a number of reports of agents disappearing with the money.

The interviews undertaken in Farah suggested that many young people were also having to engage in daily labouring work and that they were at constant risk of arrest. It appeared to be a necessary part of the process of going to Iran to seek work to have to pay agents and border guards and to also make payments to police in Iran in order to avoid imprisonment.

Whatever the balance between those engaged in relatively long-term work and those working as casual labourers and between those whose presence is sanctioned by the authorities and those constantly trying to escape detection, it was clear from the interviews that remittances were not felt to be sufficient to make more than a small contribution to the household economy.

Within the agricultural economy, it was clear that wheat was the major crop, followed by barley. In the more fertile areas, grapes and other fruit were grown, benefiting from the availability of underground water accessed through wells and, to a significant degree, from the use of water pumps. The intensive farming of garden plots is an important element of agricultural production in the districts of Bala Balouk, Pusht-e-Rud, Khak-e-Safid and Farah. The outlying districts of Anar Dara, Bakwa, Pushtuku and Shabiku have to rely on a combination of wheat and barley production and livestock. 
The districts of Bakwa and Bala Balouk have substantial livestock numbers. Elsewhere, the pattern is one of each family having, at most, a few animals.

Anar Dara is known to be a major trading centre and this was evident from its more urban feel. It also produces carpets on a reasonable scale, as does Bala Balouk.

It would appear from the interviews that the area of land which is potentially fertile is considerably larger than that which can be cultivated with present water resources. It was a common pattern in the villages visited for a substantial part of the area farmed to be only cultivated every 3-5 years. The only exceptions were Anar Dara and Bakwa, where all the land cultivated was used every year.

Farmers were clear that it would be possible to increase the level of cultivation and to also substantially increase yields if more water could be secured.

They indicated that there was some potential to provide greater access to the Farah Rud and Harul Rud rivers, and their tributaries, if improvements were undertaken to the existing irrigation systems and if flood protection structures were constructed. However, they were concerned not to rely exclusively on the rivers as a source of irrigation, indicating that the water in them decreases to a very small flow during the summer months.

Karezes exist in the districts of Anar Dara, Bakwa, Pushtuku, Shabiku and Pusht-e-Rud. Some of these have been cleared. Others remained to be worked on. It appeared to be the pattern that the young people had undertaken the necessary labouring work to bring some of the karezes into use when they first returned from Iran but had then had to go back to Iran to find work, when savings and supplies started to run out, leaving other karezes to be tackled by the older men. Progress had, therefore, been very slow as the latter had sought to balance the demands on their time relating to routine agricultural work against the need to bring the remaining karezes into use. It was thought by those interviewed that it would take some years before they would be finally successful.

In stating their priorities for possible agency interventions, farmers emphasised the potential value of work to the remaining karezes because of the fact that they provide water all year round.

Farmers were also very positive about the actual and potential value of water pumps. They frequently referred to the fact that the water table lies relatively close to the ground and can, therefore, be tapped through wells. Water pumps were inevitably found to be more effective than manual methods of drawing water and many farmers with the resources to do so had purchased these. However, it was not possible to investigate the income distribution implications of this.

Certain villages were not using water pumps at all: Anar Dara; Pushtuku and Shabiku.

There did not appear to be much use of improved seed, although some farmers reported buying it in the bazaar. The seed multiplication programme organised by CHA will have had some impact in the villages where the programme has operated.

Four of the villages were producing for sale outside the village: Anar Dara selling carpets; Bakwa selling animal ghee, buttermilk and cheese; Farah selling grapes, cucumbers, anab and animal skins; Raj Village (Pusht-e-Rud) selling grapes and raisins. 
The figures given in the appendix, and drawn from the interviews, for population per jerib, indicate that a few of the villages have a ratio of around one person per jerib. Of the others, where the ratio is less than half a jerib per person, Bakwa, Pushtuku and Shabiku have many indicators of relative poverty, and Farah has a particular focus on intensive garden farming and may also draw on the urban economy. Bala Balouk also presents as having an extremely low quantity of land per person. This could be attributable to the emphasis on intensive garden farming and on livestock.

It should be emphasised again that the figures should be treated with extreme caution. They are simply helpful as a means of raising questions as to apparent differences between villages but, in so far as they are inaccurate, may give a false picture of those differences.

As stated in the section on methodology above, the figures on land ownership need to be treated with even greater caution. However, from the information given in the interviews, which suggested that a substantial proportion of landowners were also working on the land of other landowners, one may draw the tentative conclusion that there are a few relatively large landowners and a large number of smallholders. The radical differences from one district to another regarding the degree of landlessness could relate to the relative number of smallholders in each district. Apart from Bakwa, which has an extremely low level of land ownership, there is no apparent relationship between poverty indicators for each district and the level of land ownership.

\section{Comparisons with the pre-war period}

Comparisons with the pre-war period indicate a substantially greater proportion of the population working in Iran now as compared with the pre-1978 period.

The changes to the area cultivated and to yields were recorded as follows:

Massaw Village (Pusht-e-Rud) used to cultivate some of its 15,000 jeribs on a five, four or three yearly cycle as opposed to every five years at at present.

Shuraka village (Bakwa) has increased its cultivated area from 950 to 1,000 jeribs but is experiencing lower yields.

The area cultivated in Dozbad village (Pushtuku) has fallen from 6,000 to 3,000 jeribs, on a four yearly cycle. The yield per jerib has also reduced.

Chika Village (Shabiku) was cultivating 300-500 jeribs annually before the war. It now cultivates 200 jeribs, of which 100 jeribs are used only every two years.

The area cultivated in Ginakan Village (Farah) has fallen from 4,200 jeribs to 3,500 jeribs, used on a three-yearly basis.

In Kanesk Village (Bala Balouk), the area cultivated with the use of water pumps has increased from 100 to $500 / 600$ jeribs. The area irrigated from the river has decreased from 1,900 jeribs to 1,500 . The total cultivated area is, therefore, the same. However, the 2,000 jeribs was previously cultivated on an annual basis whereas the 1,500 irrigated from the river is only cultivated every four years. 
Denau Village (Khak-e-Safid) is cultivating the same area of land as before but on a three-yearly rather than a $4 / 5$ yearly cycle. Production has, therefore, increased. This is a village in which $\mathrm{CHA}$ has been working for some years.

In two villages, Zakin Village in Anar Dara and Raj Village in Pusht-e-Rud, the area cultivated is the same as before the war. However, these villages have also benefited from many years of assistance from $\mathrm{CHA}$, including irrigation system improvements.

The figures given in the appendix for population per jerib indicate that there was a greater variation between districts before the war than there is now. The Pusht-e-Rud area was clearly better off relative to other Districts. Ginakan Village (Farah) provided a relatively low quantity of land per head of population/jerib figure before the war, as it does now, indicating a possible dependence on the urban economy of Farah city. The Districts of Bakwa, Pashtiku and Shabiku also had relatively little land per head but were, nonetheless, in a better position than they are now.

It should be noted that the population figures given in Bala Balouk did not seem credible at the time of the interview, relative to the land available, but it proved impossible to challenge them.

The number of water pumps in use appears to have increased in the Districts of Bakwa, Bala Balouk and Raj Village (Pusht-e-Rud). Elsewhere the pattern is less clear.

These comparisons indicate that the Districts of Pushtuku and Shabiku appear to have made less progress than other districts since the war.

It was evident from the interviews that livestock numbers have decreased by comparison with the pre-war period.

Those interviewed also suggested that infant mortality had reduced because of improved access to health care during the period of exile in Iran and the existence of vaccination and $\mathrm{MCH}$ programmes in Farah since their return.

Many farmers referred to a scheme organised by the Agriculture Bank before the war, through which credit could be extended for the purchase of water pumps, improved seed, fertiliser, pesticides and tractors. They also referred to the advice and guidance given to them by specialists at the Bank.

A further development of note is a substantial increase in the population. Excluding the figures for Bala Balouk, which are not felt to be credible, the total population given in the interviews for 1997 is 42,470 . This compares with a figure of 24,290 for the pre-war period, an increase of $75 \%$. This was said to be due to improved health care. The comment was made that, because families were tending to be larger, more houses were needed. The built-up area was, therefore, beginning to encroach on the cultivated area.

\section{The economic impact of NGO programmes}

The economic impact of NGO programmes overall was very situation specific. The villages which had benefited directly from previous irrigation projects, such as Anar Dara, had clearly found the 
projects useful in taking them a substantial step forward in the improvement of the agricultural economy. It is noteworthy that the districts in which CHA has been working have reached pre-war
cultivation levels.

Similarly, the villages of Massaw, in Pusht-e-Rud, and Kanesk, in Bala Balouk, expected a major impact from the irrigation projects planned by $A D A$.

There was felt to be an equally significant impact from the $\mathrm{MCH}$ and vaccination programmes of MERLIN and CHA in terms of reducing mortality among children under one year of age but the benefit of these services was inevitably felt more by the villages within easy travelling distance than in the more outlying villages of each district.

There was an apparent undervaluing of the medical service provided by the clinics, even though the impact in terms of reduced mortality was noticed. MERLIN, in seeking to restrict the dispensing of pharmaceutical products to the absolute minimum consistent with medical need and to avoid the use of injections, came up against the usual expectations that a full supply of antibiotics, syrups and vitamins would be given and that these would be injectible. There was also a strong demand for each clinic to have a doctor and MERLIN was doing its best to meet this demand, which would enable it to increase the range of drugs which could be dispensed.

The impact of road repair was only considered in one of the villages visited but it had been found to be useful in reducing the damage to crops being taken to market.

The benefits of CHA's efforts to encourage a diversification of agriculture through kitchen and vegetable gardens were less tangible. The immediate beneficiaries were clearly pleased but it was not feasible to assess to what extent others had been encouraged to follow suit.

The construction of schools was evidently popular with those interviewed. However, it was not possible to assess the likely impact of this construction. It is of interest that, in one of the villages visited, in response to a question as to whether girls from the village had been educated in Iran, the researcher was advised that this had been offered by the Iranian Government but the offer had been refused because it was contrary to cultural practice for girls to be educated. The goal of achieving equal access to education may, therefore, be a long process.

\section{The impact of the PDPA regime and the Soviet invasion}

It is of interest that there were considerable variations in how the districts were affected by the events of 1978-80. The Pusht-e-Rud district, opposite Farah city, which was an area where there was strong resistance to the PDPA regime of Taraki and Amin, suffered from large-scale arrests and killings at the hands of the regime. The district was also heavily bombed and much of the housing was destroyed. People from this district started to leave for Iran as early as 1978 and some returmed for three months at a time to fight as Mujahidin. The whole area became a battlefield in which trench warfare was used.

By contrast, the village visited in Farah district, a few miles to the west along the same plain opposite Farah city, had a mixed population of government sympathisers and Mujahidin supporters. It was, therefore, left alone by the PDPA regime but was affected by some Soviet bombing raids 
which prompted an outflow to Iran. About $20 \%$ of the population nonetheless remained and worked with the Soviet-backed Government.

There was a clear pattern whereby the districts close to the main Herat-Kandahar highway had sent people to both Pakistan and Iran whereas those further west had opted only for Iran. Those who had sought exile in Iran had been accommodated in refugee settlements in southern Khorasan and Sistan-Baluchistan provinces, unlike the refugees from Herat who had been directed to Mashhad and other urban areas within Iran, where they had had to find their own housing. It appeared that those in the refugee settlements had been encouraged by the Iranian Government to send men to fight as Mujahidin and had been given weapons and documentation to facilitate this.

\section{The return process}

The pattern of return was also of interest. There was a very clear decision by a majority of the refugees, both in Iran and Pakistan, that the fall of the Najibullah regime had removed the need for continued exodus, now that the jihad had ended. Most people had returned of their own volition, therefore. However, there came a point in 1993 when the Iranian Government decided to bulldoze the refugee settlements and to force the remaining refugees back. At this time, it appeared that almost everyone did in fact return. There was, therefore, no apparent evidence of people moving to the Iranian cities in search of work.

Instead, whole families returned, whether voluntarily or by force, and made a determined effort to repair houses and irrigation systems and get the land working again. This process was helped by the availability of savings and supplies brought from Iran. However, these savings and supplies ran out sooner or later, depending on how well off a given family was and, at that point, young people opted to try their chances in Iran. This departure of the younger element immediately slowed down the process of reconstruction because the older people who were left had neither the time nor the same degree of energy to engage in heavy labouring.

In Pakistan, however, those who chose not to return in 1992 were under no compulsion to return thereafter. A proportion had returned in 1992 in response to the ending of the jihad but many still remained in Pakistan. 
Although considerable progress has been made in restoring the agricultural economy of Farah, largely through the efforts of the farmers themselves but with the assistance of humanitarian agencies, it is of concern that a significant proportion of the population have to work outside the country, for the most part illegally.

It can also not be assumed that remittances from those working in Iran are making a major contribution to the Farah economy. In fact, it is likely, given the low wage levels in Iran, the need to make payments to ensure access to Iran, the lack of security within and the risk of theft by agents, that the amounts reaching Farah are not enormous. One may conclude from this that the benefit of sending young people to work in Iran is as much that there would, thereby, be fewer mouths to feed as that their remittances would make an important contribution to the household economy.

There are a number of possible strategies which can be pursued to improve the agricultural economy. The one with the greatest potential is action to increase the availability of irrigation water. There is some potential to provide greater access to the Farah Rud and Harul Rud rivers, and their tributaries, through irrigation projects.

It would also be of benefit to clear the karezes which are still not functioning. Because this task is unlikely to be completed within a reasonable period of time without the involvement of some of the young people presently in Iran, there may be a case for payment being offered to encourage a number to return and undertake the work. This could be problematic in so far as it is against the policy of many agencies to pay for the clearance of karezes on the grounds that this is a task which has traditionally been undertaken on a voluntary basis. However, the circumstances are such that a change in policy could be justified. The UNDP P.E.A.C.E. Programme might be a suitable vehicle for such an initiative.

There is also potential to improve agricultural production through the greater use of handpumps. However, it would be impossible to provide handpumps to every farmer but, at the same time, any system of targeting could be problematic. The credit system which existed before the war would certainly be useful now but it is not easy to see how such a scheme could be organised under present circumstances.

The provision of improved seed, fertilisers and pesticides could do much to improve yields. Training through agricultural extension would also be valuable.

The key question, however, is whether, given a further injection of resources to strengthen the agricultural economy, it would be possible for that economy to sustain the entire population, including the young people working in Iran. The fact that, in the three districts visited where agricultural production had reached pre-war levels, a significant number of young people are still going to Iran suggests that total selfsufficiency may be difficult to achieve. This does not mean that every effort should not be made to move towards self-sufficiency, given the difficult circumstances under which young people are having to work in Iran and the ever-present possibility that the Iranian authorities may tighten up on their controls. 


\section{Recommendations}

(a) That continued assistance be provided to assist in the process of further strengthening the agricultural economy of Farah, particularly through programmes to increase the supply of irrigation water.

(b) That payment be offered for the clearance of the remaining non-functioning karezes so that some of the young people presently working in Iran may be persuaded to return to undertake the necessary work to bring them into use. 


\section{Case studies}

\subsection{Massaw Village, Pusht-e-Rud District}

\section{Description}

Massaw Village is situated across the river from Farah City in the Pushtrud District. It is, therefore, in a strategically important location. This inevitably influenced its level of vulnerability to the Soviet military presence. The uncultivated land around the village is covered in rough scrub over a large area. This gives a visual impression of a vast expanse of green, interspersed with domed mud houses clustered in villages. This land is potentially fertile and, with greater access to water for irrigation, the cultivated area could be increased very substantially. Afghan Development Association is in discussion with the village structures regarding improvements to the major canal which serves the area.

The visit was facilitated by $\mathrm{ADA}$.

\section{Villagers' testimony}

This is a large village, consisting of seven small villages. It is fed by a long canal, 25 kilometres in length, which has nineteen smaller canals. There is, potentially, a significant amount of irrigated land. However, because of the limited availability of water, we cultivate some of the land on a five yearly cycle. This ensures that a reasonably large area retains its fertility 15,000 jeribs are cultivated on at least a five-yearly basis. Of these, 8,400 jeribs are cultivated every year. We use pumps to irrigate some of the land. Before the war, we cultivated the same area of land and, depending on water availability, cultivated some of it on a five, four or even three yearly cycle. The irrigation system is not functioning as well now as it was then.

There are now about 800 families in the village, which makes about 8,000 people. There are about the same number of families as before the war but the population has grown because more children have survived and a new generation has produced children. Before we went to Iran, every family had about five children. Now, it is not uncommon to have fifteen.

We grow wheat, cotton, pomegranates, grapes, barley and a few other things. We largely rely on wheat. We plant in the autumn or winter and harvest in the late spring. Those who have tractors can grow other produce. It was just the same before the war. However, we haven't reached prewar production levels. We still don't have enough fertiliser, irrigation water or tractors. We need more of all these things to get production up to and beyond pre-war levels. There is no double cropping. We tend to buy poor quality flour because the high grade is too expensive. However, we have to use high quality seed. We buy improved seed from the bazaar. Before the war, the Government gave help with tractors, fertilisers, water pumps and improved seed - on credit.

We only have water up to the first month of summer. We have been working on the canal by hand, but every year it has been destroyed by the floods. We have continued to construct intakes, using soil. We are using the canal now but it is far from perfect. We are in discussion with ADA about them undertaking improvements. Other organisations have come to see us about it but retum and reconstruction 
nothing happened. One foreign organisation came but they insisted that we bring stones for the gabions and that we also pay $30 \%$ of the cost of the work. If there is easy physical work to do, we can help but we can't manage to bring stones from the mountains or pay money. We could grow cotton and carrots if we could irrigate more land.

We don't have any animals to speak of. Some houses have the odd cow or donkey for transportation. It will take years before we can even finish our houses. We can't afford animals. Before the war, some people had as many as twenty cows but we lost everything in the fighting. We don't even have enough crops to survive on. We have no surplus to sell in the bazaar. Before the war we had contracts to sell apples to Kandahar and wheat to Herat. Also, Government cooperatives were buying from us.

We have plenty of agricultural land. The main problem is getting water to irrigate it. Half the population of Farah is drawing water from this canal. It is very important.

There is only one tractor in the village. Before the war, there were plenty.

Some people with enough money have started to create gardens but these have yet to produce fruit. Before the war, there were a lot of orchards and gardens for grapes, pomegranate, apple and apricot. One grape bush can produce 80 kilogrammes. They are all destroyed now. We also used to have vegetable gardens but not any more.

About 30 families are landless sharecroppers. They receive $25 \%$ of the crop and the landowner provides all the inputs. Most people own some land but about half of these have to work as sharecroppers or as labourers on other people's land. Some of those without land go to work in Iran.

Every family has between one and three members working in Iran. These are mainly the very young people, primarily teenagers. They work as daily labourers, on construction sites or in farming. Sometimes, they are able to send back money. At other times, if they can't get work easily, it doesn't prove possible. They tend to come back once a year to see their families. It very much depends on the economic situation here as to how many go to Iran. If the situation got bad enough, even the old men would go.

People first started going to Iran during Taraki's time. They were picking people up in large numbers and killing or imprisoning them. After the war, they found a mass grave with 2,000 bodies. People went to Iran at this stage because it was their Islamic duty to migrate when attacked by an infidel. When the Soviet forces came, they bombed the village and shot at people from helicopters. On one day, 475 people were killed. The village was largely destroyed. Everyone left then. The village became part of a battlefield. Those who were willing to fight as Mujahidin would come back to this area for three months at a time and then return to Iran for three months. People would rotate so that one family would look after the family of the other, who was away fighting, as well as his own, and then have his own family looked after while he went off to fight. The Iranian Govemment provided us with guns and with documentation to enable us to go back and forth across the border. We continued to fight even after the Soviet troops had left because there was still a Soviet-backed government in power.

When we went to Iran, we were sent to a place in the middle of the desert 30 kilometres from Birjand where we built our own houses. The refugee village was called Shamsabad. We stayed in 
Shamsabad for thirteen years. We returned after the Mujahidin had taken power in Kabul in April 1992. We no longer felt obliged to remain as the jihad had ceased. As we left our homes, the Iranian Government demolished them. At first, it was optional for people to leave but, in the end, we were expelled by force. Everyone came back to Afghanistan. Only those who had moved at a much earlier stage to other parts of Iran stayed there,but these were a minority - only about $5 \%$.

When we returned, the first priorities were to clear the karez of mines and to rebuild our homes. There were also a few mines to be removed around trenches dug during the fighting. We got help with mine clearance from a specialist organisation.

It wasn't that difficult when we first came back. We brought wheat, oil, tea, sweets and other things from Iran. We also received help from UNHCR at the border - wheat, cash and plastic sheeting. However, the Iranian Government was taking half the wheat and cash from us and keeping it for themselves. It was useful to have this assistance, nonetheless. During the first year, we just cultivated wheat.

However, our reserves ran out after a while and it was then that the young people started to go back to Iran.

Our major need at the moment, apart from water, is for fertilisers, improved seed and tractors, with or without credit. We would also welcome a clinic and a school. 


\subsection{Zakin Village, Anar Dara District}

\section{Description}

Anar Dara is situated in the north-west of the Province and is the last settlement before one of the crossing points into Iran. It is said to be engaged in smuggling in addition to the economic activity recorded in the interview. The village consists of two storey buildings constructed of mud and is characterised by winding streets. It is a large village with its own bazaar. It is surrounded by a stony desert with a mountain backdrop.

The visit was facilitated by CHA.

\section{Villagers' testimony}

The present population is about 5,600 people. Before the war, there were about 3,300. The population is higher now because people were healthier in Iran and more children survived. The vaccination programmes here in Afghanistan have also increased survival levels.

We mainly cultivate wheat and barley. About 5,000 jeribs are cultivated now but we could cultivate 7,500 jeribs if we had more water. We were also farming 5,000 jeribs before the war. We plant in the autumn or winter and harvest in the early summer.

We grow more wheat than barley. We also grow some cotton, pomegranates and a local fruit called anab. However, yields are low because of grasshoppers. Pomegranates tend to be particular targets and they often rot.

Before the war, we grew two thirds wheat and one third barley. We also grew melon, water melon, pomegranates and cotton. In those days there were fewer insects. If we had problems, we used to get insecticides from the Government. We have had no help with insects since we came back.

Before the war, the level of cultivation very much depended on how much rain there was. If there was plenty of rain, the karezes would have a lot of water and we would be able to cultivate quite a large area. However, in years of low rainfall, the karezes would sometimes dry up and we could only cultivate part of the land. We also used to get water from the river. Water from this source was more important then than now. But the river water is only available for four months of the year, whereas that from the karezes flows for the whole year. We also now use a spring which CHA has tapped into and brought to the village through a long canal.

There are five tractors in the village. They are all owned privately. We had no tractors before the war - only oxen.

People consume the wheat and barley that they produce. There is nothing left to sell outside the village. However, we produce carpets for export. Each family has one person making carpets. It is only the women and girls. It works out at about one dollar per day that they earn. We have problems finding suitable colours and also obtaining string. There is also a shortage of looms. We don't use natural colours. There are some small merchants who buy the carpets and take them to Herat for onward sale in Europe. 
Nomads graze their animals in the village but people from the village do not live from livestock. Every family has a cow and a few have hens and turkeys, for their families' needs. We had far more livestock before the war.

About two thirds of the people in the village own their own land but this is not enough for most of them. Some have more land than others. About half the landowners have to work on other people's land as well as their own, to survive. Those without land go to Iran, particularly the younger people. They mainly do daily labouring work there. The older people stay here and do odd jobs like collecting wood. About $80 \%$ of the young people are working in Iran. About 50 families are sharecroppers. Before the war, a few young people went to work in Iran but nowhere near as many as now.

Fighting started in this village from Taraki's time. The village was then bombed by the Soviet forces. Many were killed. Most went to Iran, where they lived in a refugee village near Birjand. Some people remained in the village and continued to cultivate the land as best they could.

People came back gradually after the fall of the Soviet-backed Government in 1992. Those who were slow to return were finally forced to leave when the refugee settlements were bulldozed by the Iranian Government in 1993. We had ration cards entitling us to food and cash from UNHCR but these were torn up by the Iranian Government. However, this only happened at the beginning. Those who came later received assistance at the border. When we first came back, we could only cultivate about 2,000 jeribs. We had to clear the karezes and the houses had to be repaired. CHA helped with the deeper karezes and we repaired about four. We survived during that year on what we had saved from Iran.

The young people started to go back to Iran fairly early on after the return, particularly when the savings began to run out. They have to go into Iran illegally. If they are caught, they risk being put in prison for two months and then being deported. However, they still keep on going back even after this experience. They have no choice. Most manage to send some money back. No-one has gone with their families. When young people get married, they leave their families behind and go back to Iran.

During Zahir Shah's time, an American organisation came and provided us with some assistance to improve the karez. We then had no aid until after the Soviet forces had left. The commander from this area went to Pakistan and asked CHA to come and help. He was concerned to increase the water supply to the village in order to stop people leaving. CHA surveyed the area and agreed to work on the karez and the spring. We are still engaged in the process of connecting up our land to the supply; which CHA helped to create. The young people are not here so the work is slow. But most of the work is now done. It was certainly useful to have CHA to undertake the initial work. It has made it possible for us to make very much more progress. 


\subsection{Shuraka Village, Bakwa District}

\section{Description}

Bakwa is situated on the edge of a bleak black desert adjacent to a range of forbidding black mountains at the foot of which is a thin fertile strip. The inhospitability of the environment was aggravated at the time of the interview by a strong hot dusty wind which was blowing. The area is well known for its intense heat. The District is a relatively short distance from the main HeratKandahar highway and can, therefore, link as easily with Pakistan as with Iran. There is only one settlement of significance in the three hour journey over black mountains and desert from Farah to Bakwa which is dramatic in its desolation.

The visit was facilitated by MERLIN, which has a clinic in the District.

Villagers' testimony

The village has a population of around 650 families. Before the war there were fewer families than now - perhaps 500. There are 35 families presently in Iran and about 20 in Pakistan. Those living in Iran are in Zahedan, Zabul and Iranshahr. The families in Pakistan are in Karachi and Quetta However, the population consists mostly of young people who are working in Iran. Life is difficult for them. They have to find casual labouring work.

We grow wheat, corn, mash and zira, and also keep livestock and make carpets. Altogether we have approximately 900 jeribs, irrigated by karezes.

We also have 25 water pumps irrigating an additional 100 jeribs. Before the war, we were irrigating about 50 jeribs. We have benefited from going to Iran and Pakistan and have learned new techniques. We have also managed to bring back water pumps.

However, our crop yields are lower. now than before the war, because of water shortages and because we do not have enough money to buy fertilizer. We continue to cultivate the land every year.

We have camels, cows, sheep, goats and donkeys. There are approximately 25,000 sheep and goats in the village, whereas before the war we had about 30,000. We have between 500 and 600 camels, and about 50 milk cows.

There are three karezes serving the village, which is the same as before the war. However, they used to produce much more water so we were able to cultivate more land. The karezes need cleaning. They have not been cleaned since the Soviet period, and are full of mud and gravel, but we do not have enough time to do the work or enough money to pay anyone. People are already fully occupied trying to survive. If we had to start working on the karezes, we wouldn't have enough to eat. We don't have any tractors, but we didn't have any before the war either.

We never had orchards, but now some people are putting in one or two mulberry trees and grape vines near their water pumps. This is for local consumption. Some villagers grow a few vegetables for their families. We sell animal ghee, buttermilk and cheese, either locally or through traders, bartering them with wheat or cloth. 
We plant in October and November, and harvest after six or seven months. There is no double cropping. We receive no help with seeds, fertilisers or pesticides. We don't receive any veterinary assistance either, even though there is a veterinary clinic near the village. It is helping nomads in the mountains, not us.

There are about 100 families with land. Those without land are more likely to have their sons working in Iran and Pakistan or to be living there as families; some are shepherds, and some are working with other farmers. We have a share-cropping system, through which the share-cropper receives $20 \%$ of the crop in return for the owner providing seed, etc. Of those who have land, there are many who cannot survive exclusively from the land; they graze animals and have some family members in Iran and Pakistan. Before the war, there were people working in both Pakistan and Iran, but only a few. There is no-one working as a daily labourer in the village.

When the Soviet forces came, men from the village went to fight with the Mujahidin. Many people left the village; some went to Iran, some to Pakistan, and some to the mountains. Those who left for Iran went to Zahedan, Zabul and Iranshahr. Those in Pakistan went to Quetta and Karachi. Half the families went to the mountains, where they lived in tents. Most lived on bread alone. Some grew potatoes. The young men from these families went to Iran to find work. Our village was not bombed. Some of the old people would come from the mountains to the village to look after the land. They were not able to grow as much as before. How much they grew depended on whether Russian tanks and helicopters came to the area. When the Soviet forces left, we remained in the mountains until the Najibullah regime fell; there was still fighting in the area. People also came back from Iran and Pakistan at that time. More came from Iran, some of their own volition, and some by force. Some families received entitlements at the border, whilst others didn't. All of those who had been living in refugee camps in Pakistan received assistance, whereas those coming from Karachi got nothing.

When we first returned, priority was given to house building and repair, since many of our homes had suffered from years of neglect and exposure to the elements. The old men in the village had continued to work, so when people came back, they had the young men to help them. During the first year or so, we were relying on what we had saved in Iran and Pakistan, along with any assistance people had received at the border. Some of the young men started to go back to Iran after about six months. Some of them have been put in prison camps. Nobody is happy to go to Iran, but the economic situation is so bad that we have no choice. A few of our villagers are fighting with the Taleban; we have collected money from all the families in the village to give to five or six families so that they can send one son each to the Taleban.

To improve the economic situation, we would put the cleaning of the karezes as the priority. If these were cleaned, we would not need to send our young people to Iran to work. We also need improved seed, fertilizer, tractors and water pumps. In Daoud Khan's time, we received fertilizers, oxen and seed. We haven't been to Farah to ask any NGOs for help, nor have any come to offer us assistance.

We do use the MERLIN clinic; it is better than nothing, but it would be useful if they could increase the service, by providing doctors, more drugs, injections and serums. At the moment, it is only useful if you have a headache. If someone gets ill, they go to Lashkar Gah or Farah; there are some health workers who sell drugs at a high price in other villages of Bakwa District. We have had discussions with the MERLIN health worker and expressed our concern that Dextrose injections are not available; we are also asking for some infusions which are good for patients who have lost liquid, are dehydrated or cannot keep food down. 


\subsection{Dozbad Village, Pushtuku District}

\section{Description}

Pushtuku is the most northern of two districts, Pushtuku and Shabiku, which make up the larger District of Qala-i-Koh in south-western Farah. Although it has relatively easy access to Iran, it is not a trading centre unlike Anar Dara. The area has relatively little cultivated land. It is surrounded by a flat desert of scrub and loose sand. Damaged karezes and canals are very much in evidence.

The visit was facilitated by MERLIN which has a clinic in the District.

Villagers' testimony

There are now 500 families living here. Before there were only 320 families, but the number has increased because family income has increased over the past 23 years, and people are now more able to have their own houses. Now there are very few children dying during their first year, whereas before the war, $85 \%$ of under one year-olds were dying. There were then no vaccines and no facilities; this village has benefitted particularly from proximity to the vaccination centre.

Now we cultivate about 3,000 jeribs of land; before the war it was more like 6,000. We cultivate on a four yearly cycle because of the shortage of water in this area. We make our living entirely from agriculture; we harvest wheat and barley, and only own a few animals. Our yield per jerib is less than before the war. Only a very few families grow vegetables, and then only for their own consumption; a few have some grapes. The animals we raise are cows and sheep; most families have one milk cow, but there are only 800 sheep in the whole village.

Our land is irrigated from the river which comes from Anar Dara and Shindand. Water only comes during the winter, and there is not enough during the summer. We have two karezes but both need cleaning; we don't have time to clean the karezes and to earn a living. We do not have any water pumps but there is plenty of water ten metres below the ground, so water pumps would be very useful for us. The small channels which bring water from the river have been destroyed by floods, and in spite of doing all we can, it is impossible to mend them without stones and cement, which we cannot afford. The force of water is sometimes so great that a gabion structure would not withstand it. Water is therefore our main problem; we lost 20 tonnes of wheat this year due to flooding.

There is a canal which brings water from the river to the village, and for a two kilometre stretch, it has an extremely weak bank on one side. As a result the water escapes onto the surrounding desert. We need to make this bank particularly strong; there are 72 villages using the water from this canal.

We do not sell anything; our wheat plants are very weak because of the water shortage in the area. Before the war, the irrigation system was much better; we were able to sell wheat in Farah, Anar Dara and Kandahar. The river is wider now than before; this is because we have had to neglect the river course. Before, people used to direct the flow of the river. Due to neglect during the war, it has now found other channels and has become less controllable. We try to use bushes and stones to direct the flow of water, but we really need to do a proper job with cement. We would find it very helpful if an NGO were able to build some flood protection structures; this would benefit the whole of Pushtuku, not just our village. 
There are three tractors now in the village, but none of them is in good condition. They are sometimes used on the owners' land, but they are not in a condition to be hired out. We had three or four tractors before the war, but they were damaged or destroyed during the fighting.

We do not double crop in this village, but plant in October or November and harvest six to eight months later. We have a particular plant disease in this area called Siak, which we have had since before the war; there is no treatment for it. We do not receive improved seed; but we would need more water in any event if we were to use it. The new seed also needs more fertilizer; before the war we received new seed and fertilizer from the government. They used to charge us a small amount for this - the government took $20 \%$ to cover the transport costs. Before the war we were able to make good use of the seed and fertilizer because we had enough water; at that stage, we didn't need water pumps. We could buy tractors on credit from the government, and repaid the money over five years.

About half of the families in this village are landowners and about half are not; only $10 \%$ of families here are able to survive on the land; the other $90 \%$ survive by the young people going to Iran. There are two disabled people in the village; they have a bit of land and are otherwise helped by others. None of the widows in this village lives alone.

Many of the young people going to Iran leave their families here. About 100 families are actually living in Iran, in Kerman, Rafsanjan and Zahedan. Young people who go away send money back once or twice a year only but do not make a major contribution to the local economy; their earnings are low and work is not reliable. Before the war, none of the young people went to work in Iran because there was no need for them to go. If we could improve our agriculture, young men would definitely not go to Iran, and we might even be able to employ labourers from the other villages.

During the war, 35 people stayed in the village; they were either too poor or too old to leave. There was heavy fighting, and bombing. Many young people were arrested or conscripted, even during the period of Taraki and Amin. People started to leave during that period; everyone went to Iran because we are close to the border; we went to Birjand, Zahedan and Zabul. We were living in refugee villages there, and returned after the fall of Najib. We all came back together in one week in 1993; the Iranian Government provided us with transport. Many of the villages had been destroyed; nobody had come back before us. About $5 \%$ of us received assistance at the border; most of us did not cross at one of the crossing points where UNHCR were giving out the assistance package.

During the first year we survived on what we had saved from Iran, and we planted the same year; we had a problem with mice at that time. The young people started to return to Iran after two months, depending on their economic situation, and their level of savings. When we first returned, the main problem was shelter, and after that, the karezes. People helped each other with house building, but we have not done any work on the karezes. Now there is a veterinary clinic in the bazaar, a MERIIN clinic and a vaccination service provided by CHA. These are all useful. Nobody from any of these organisations has come to our village to discuss any of the problems we have, except for the CHA supervisor. We are especially pleased with the vaccination service, which has helped to decrease the infant mortality rate here. We would welcome the presence of a doctor and perhaps a greater range of pharmaceutical drugs. There is no primary, secondary or madrasah school here.

One of our young men returned yesterday from Iran. He had spent 45 days in prison; all his savings were taken from him, he was beaten and received little food. He is very weak. When young people are picked up in Iran, if they give money to the soldiers they are alright. Otherwise, they are given a lot of trouble. 


\subsection{Chika Village, Shabiku District}

\section{Description}

Shabiku District is sitauted immediately to the south of Pushtuku District in the south-west of Farah Province. Like Pushtuku, it is surrounded by a sandy desert and has a relatively limited area which can be cultivated. Chika Village relies for irrigation on two karezes, one of which still needs to be cleared of silt and earth. ADA plans to build a school in the district but does not normally undertake karez repair. This could, perhaps, be appropriately tackled by the UNDP P.E.A.C.E. programme. MERLIN operates a clinic in the district and CHA provides a vaccination service.

The visit was facilitated by MERLIN, which has a clinic in the District.

\section{Villagers' testimony}

The population of this village is approximately 160 families. Before the war, there were almost 100 . There are, in addition, 60 or 70 families from the village living in Iran. Now, we cultivate about 200 jeribs; 100 are cultivated every year, and the other 100 every two years. Before the war, we were cultivating between 300 and 500 jeribs. All of this land was cultivated annually. We used to get 100 kilogrammes per jerib before the war; now it is only half that. People were away from the land for 10 years, and when they came back, there wasn't enough water, seed or fertilizer.

We have no income except for agriculture. Some families have one or two animals, but we don't produce any carpets here any more. We used to make them before the war, but now we don't have the materials. About 120 young people are still working in Iran, mainly in brick kilns, or earning daily wages in construction work.

We grow wheat and barley, which we plant in the autumn, and then harvest at the end of spring. We do not double crop. Some families grow vegetables for themselves, but we don't grow any grapes at all. We have cows, sheep and goats in the village - about 700 sheep and goats - and about 30 cows. We depend on karezes for our irrigation; we have two karezes, only one of which is giving water. The other one needs to be cleaned. We have been working on it for four years, but we still haven't got water going through it. There aren't any young people able to do the work, and we think it will take at least 10 years to finish. We really need assistance.

We don't sell anything from this village. We have one tractor, which is better than before the war, when we didn't have any. However, this one is not really working. We have a few mulberry trees in the village. We used to have a few more trees before the war.

We have not had any help with seed or fertilizer, but then we didn't get any help from the government before the war. There was nobody working with the Government; those villages that had people working in the government were the only ones able to get assistance. Our village is heavily dependent on the young people who go to Iran. If these young men manage to spend a reasonable amount of time in Iran, they can make a good contribution to the local economy; if they only go for a month or so, they are not able to help much.

Young people going to Iran have to pay someone to take them across the border, and they also 
pay the soldiers. When they are picked up by the police, they can secure their release from police stations by making payments.

Forty families in the village have no land. Of those who do have land, only about five families can be self-sufficient. The very poorest families go to Iran. There are also bits of work here cutting wood or helping with the harvest. We do not have any share-cropping. Before the war, nobody worked in Iran, and, if the second karez was functioning nobody would need to go to Iran now.

Before the war there were disparities between villages, depending on their economic situation. There are still differences between villages but much less than before. If the Iran border is open, there is much more trade and more opportunities to make money and this increases the disparities. Nobody from this village is engaged in trade because they do not have the necessary finance.

People started leaving for Iran from Amin's time, when there was a lot of fighting. One bomb fell very near the village. When people left they went to Zabul, Khorasan, Tehran and Bandar Abbas so we were all widely scattered; most people were in three camps - near Birjand and Nehbandan. People survived in the camps because young people went to the nearby towns to do daily labouring work. The Iranian Government provided a small amount of assistance.

People returned gradually from 1992. Of those who were living in camps, $95 \%$ came back to Afghanistan, whilst $5 \%$ went to other cities. It was mainly young people who stayed behind. However, the young people who came back started to return to Iran as soon as ten days after their departure. It very much depended on the financial situation of their families. We survived initially on savings which lasted for three to four months. We received no assistance. Our first priority was to rebuild our homes, and we also started work on the karez. Every day, 50 young people would go to the karez and clean it, but this was only during the early months when we still had savings. No outside organizations have helped us with agriculture

The children are using the clinic provided by MERLIN; people go to the clinic if they have ear infections; if they don't get better, they go to Farah city. The clinic is better than before, now that there is a doctor there. Everyone uses the clinic now, except those who live in villages too far away, and who therefore go to Farah. The clinic has been there for 14 months, and now only $10 \%$ of children die in their first year. Before the clinic came, it was about $50 \%$.

We would like a school as there is no school at the moment, and we would also like help with seed and fertilizer, but the karez is our priority. ADA sent a survey team a few weeks ago to look at the possibility of building a school, and they plan to build one. 


\subsection{Ginakan Village, Farah District}

\section{Description}

The village is ten kilometres from Farah city on the opposite bank of the river. It is, therefore, part of the same relatively fertile plain on which Pusht-e-Rud is situated but further to the south-west. Because the village was in the same administrative district as the city itself, it was in an ambivalent position in relation to the PDPA Government and the Soviet forces. As a result, some of the population worked with the Government while others supported the Mujahidin. The village population includes a relatively high number of people with professional qualifications or technical skills.

The visit was facilitated by ADA.

\section{Villagers' testimony}

The present population is about 500 families - approximately 3,500 people in total. Before the war, we had around 700 families - about 4,900 people. The population has not yet returned to its original strength because there are 400 families in Iran and Pakistan. $90 \%$ are in Iran. These families are in Yazd, Zahedan and Kerman. On top of this, the young people of the 500 families here are in Iran.

We cultivate around 3,500 jeribs of land now, of which $10 \%$ are gardens and are cultivated every year. These are irrigated by water pumps. The rest of the land is cultivated on a three yearly basis. There is an additional 500 jeribs which produces nothing because of the shortage of water. Before the war, we cultivated 4,200 jeribs, also on a three yearly basis.

We grow wheat and barley, as well as tomatoes, peppers, cucumbers, water melons, squash, pumpkins, and other vegetables. Most of our land is used for wheat, as it was before the war. There is no double-cropping. We normally plant in December but, if the rains are delayed, we wait until January or February. We harvest at the end of May.

There is a small canal coming from the Farah Rud River and we use this for the fields; we also use water pumps for the gardens. We have 100 wells, but we do not have enough water pumps to draw from these. We only have about twenty pumps. The water table is very high here. Before, we had the same irrigation system, but without the water pumps. We used manual methods to extract water from the wells. To increase the area of irrigated land, it would be better to have more water pumps than improve the canal, as this dries up in the summer.

We have done some work to improve the road through gravelling. The work has been done by a couple of outside agencies, CHA and VARA, and we had to make a $30 \%$ community contribution, through the provision of labour.

There are four tractors in the village, whereas we only had one before the war. The tractors are hired out.

We have gardens for grapes and vegetables, but we had more before the war; about $10 \%$ were destroyed during the war. 
We sell grapes, cucumbers, anab and animal skins in the bazaar. We sell quite a lot of grapes, but animal skins only represent about $1 \%$ of the economy.

We are also planning to start up a poultry farm, to be shared between villages, but we don't have any chickens yet.

Our main problem is a shortage of irrigation water, mechanisation, fertilizer and pesticides. Improved seed is not available either. Before the war we had agricultural specialists to advise us; now there are none. We also received help with seed, tractors, and water pumps on a credit basis or at half price before the war. We need help with pests, particularly for grapes.

About half the village has land and the other half does not; the average is about four jeribs per family. Only about 100 families have more than four jeribs, whilst 350 families have less than this. These families work on other people's land, either here or in other villages, or they go to Iran. This was the same before the war, though only about $5 \%$ or $10 \%$ worked in Iran. Some vulnerable families do carpet weaving, or they are helped by other villagers.

Apart from cultivation, we rely on livestock and have 600 sheep and goats and 350 cows. Before the war we had 900 animals - about 250 cows and oxen, and the rest were sheep and goats. We use the animals primarily for milk, but also for oil and for meat, and we sell the skins in the city.

Some of our younger people are working in Iran, and we also have a little income from carpets. Nobody is working in Farah city, as it is not a big enough city to provide work for young people. $10 \%$ of young people are living here, and $90 \%$ are working in foreign countries, but the money which is being sent back from Iran and Pakistan is not significant, at least not enough to keep families. We mainly survive on the wheat we grow. Our young people in Iran are not happy, and if, in the future, it proves possible to stay here, they will do so.

During the period of Taraki and Amin, we had no problems. However Soviet forces bombed the village. About $80 \%$ of the villagers went to Iran gradually over about 3 years. We went to both Khorasan and Sistan - Baluchistan: We were scattered across seven or eight refugee settlements, including Shamsabad and Nehbandan. None of us went to Mashhad. We lived in tents at first and then built our own houses with mud. We started to come back from 1992 onwards. Most came back gradually over a year; the Iranian government destroyed the houses in all the settlements. A few went to other parts of Iran immediately, but most came back to Afghanistan. Quite a lot went to look for work in Iran when they faced difficulties on their return. However, they did not go back to the same places. It was mostly the young people.

During the war $20 \%$ remained, and $80 \%$ were refugees in other countries. The $20 \%$ who remained worked with the Government and were supported by it. However, others from the village were coming in from Iran to fight with the Mujahidin.

When we returned from Iran, a few were able to get some assistance, but most didn't get any help. Our first priority on our return was to repair our homes and the canals and to get the gardens cultivated. There were also mines on the main road but not in the village area.

We didn't receive any assistance from outside agencies before ADA came to the village. We took the initiative to contact $\mathrm{ADA}$ about the construction of a school, which is a fundamental need. ADA didn't 
have a water pumps programme, so we asked them to build a school. There is a school already but it is built of mud, and it is better to have a proper construction. It will also cater for more children.

We have another problem: flooding has destroyed 2,000 hectares of land, and also the Pusht-e-Rud road. Half the cultivated area has been affected. We built some protective structures but they were destroyed, so we have asked ADA to build a permanent structure. Culverts on the road would also be useful. We made a new request today. Maybe ADA will be able to do something for us. We will have to make a $30 \%$ contribution, as we have done with the school but we are always ready to do this. For the school, we provided stones, gravel and sand and also helped with excavating the foundations. For the flood protection programme, we will provide labour. Because we are an educated population we have good relations with NGOs.

We would also welcome a clinic, as we have to go to Farah city. There used to be a Government clinic during Najib's time, but it has been destroyed. If we had a clinic, we would use it for cholera and typhoid vaccinations. It would benefit 10-12 villages. The MERLIN clinic in Pusht-e-Rud is further from our village than the city is. The main illnesses here are malaria, typhoid and TB.

A few young people are fighting in other parts of Afghanistan, but they are doing this for economic reasons. There is a risk of poppy cultivation increasing if the economy is not improved.

If we were given credit, we would be able to bring more land under cultivation through the use of water pumps and tractors. We could also develop the carpet weaving. 


\subsection{Kanesk Village, Bala Balouk District}

\section{Description}

Bala Balouk is situated astride the Farah Rud river, to the north-east of Farah City. The area is potentially fertile to the extent to which water from the river can be accessed and underground water can be tapped. Kanesk Village is some kilometres away from the river and is, therefore, dependent on a canal which draws water from the river through an intake. The present intake is only effective when the river is at its height. ADA is planning to improve the intake so that water will still flow into the canal when the water level in the river subsides and so provide irrigation water for a longer period. At present, the village relies largely on underground sources accessed through water pumps and there is a consequent emphasis on intensive garden cultivation.

Bala Balouk is unusual among the districts of Farah in having sent most of its population to Pakistan rather than Iran in response to the events of 1978-80. This is a consequence of its proximity to the main Herat-Kandahar highway but Bakwa, which is almost as close to the highway, had a significant minority of its population in Iran. This may be a result of Bakwa's relative poverty and the possibly easier access to casual labouring work in Iranian cities.

ADA has four projects in the district:

1) the improvement of the canal intake on the Farah Rud river

2) the construction of a school

3) an educational project

4) a school-based training programme in agricultural techniques, through the use of a demonstration plot.

The visit was facilitated by ADA.

Villagers' testimony

Our main problem here in Kanesk is water - the fields are dry and we don't have enough crops. The population of the village was approximately 24,000 before the war; now we have only 8,000 people. Most are refugees in Pakistan - in Peshawar and Quetta. There are relatively few in Iran. Those that are living in Zahedan, Zabul or Mashhad.

We now farm 2,000 jeribs, of which 1,500 jeribs are farmed on a four yearly cycle. The other 500 are farmed every year. Three years ago we built, with our own labour, a canal which brings water from the Farah Rud river, but it was destroyed by floods. Before the war, we irrigated the land manually or with the help of bullocks. Then, only a few people had water pumps, which we used to draw underground water to irrigate the fields. We managed to irrigate 100 jeribs by water pump before the war, using only a couple of pumps provided by the Government; now, most people have water pumps, and 500-600 jeribs are irrigated. We have always taken some water from the canal leading to Farah Rud, which irrigated 2,000 jeribs before the war. If it were rebuilt, it could again irrigate 2,000 jeribs every year.

Most of our income comes from the cultivation of crops, but we also depend heavily on livestock; 
the women from all the families here make carpets, since our people in Pakistan and Iran are not sending money. Mostly they are with their families, though some are on their own. It is difficult for young people to find work, so some go to Pakistan and Iran. At the moment there are around 1,500 young people in foreign countries, and some of these are sending money.

Our main crops are wheat, maize, clover, barley, cotton, some rice, water melons, melons and cherries. Most of these are garden crops, but wheat is the most important. We grew the same crops before the war. Our livestock consists of sheep, goats, cows and ducks, of which we had 20,000 before the war. Now we have 10,000. We don't sell any agriculture produce - we are still not self-sufficient.

We have five tractors in the village which are privately owned. They are hired out to others. There were 50 tractors before the war. They were given by the government without any payment or credit.

We also had 600 orchards before the war, whereas now there are only 100. We grow apples, grapes, pomegranates, anab and two varieties of cherry. We also grow vegetables: onions, tomatoes, potatoes, and egg plants. This is the same as before the war.

We plant wheat in December and harvest it in May. Then, in June, we plant a spice which is served with rice. This is harvested in November. We do this on all our land, but we don't sell the spice. We just use it for our own consumption.

We have problems with seed and fertilizer, with tractor shortages, and with flooding from the canal, which can damage the crops. We also don't receive any pesticides, so have trouble with pests. We get no improved seed at present; before the war, during the Daoud regime, we were given free seed. The Government also used to give us money to buy animals, and when we sold them the Government would get half the proceeds. The Government also provided veterinary clinics - neither the Government nor NGOs provide veterinary support now. About $5 \%$ of the village have no land; most landowners are also working for other farmers, which is the same as before the war.

When the Soviet forces entered Afghanistan, a lot of people became refugees; some stayed in the country and fought. People started to leave during Taraki's time. During that period about 500 people were killed, and the village was bombed at least 100 times. Despite this, about 1,000 people stayed throughout the war. Of those who left, most went to Pakistan and a few went to Iran. 2,000 people returned from Pakistan after the fall of the Najibullah Government in April 1992. The others haven't come back yet because of the economic situation here.

During the Soviet period, we faced particular difficulties because the Russian forces used to burn the crops. After the Soviet troops had left, those of us who had remained during the war were able to begin the process of increasing cultivation. When people returned from Pakistan in 1992, they had to rebuild their houses; We also started repair work on the canal from the Farah Rud at that time, but it was destroyed by flooding. Those who returned from Pakistan were not given any assistance at the border.

In 1996, we made contact with $\mathrm{ADA}$. When the $\mathrm{ADA}$ survey team came, we requested that they build a school and also work on the canal. We had seen ADA projects in other parts of Farah and had liked what they had done, so we asked them to work here. We hope that, when the school and irrigation problems have been solved, people will start to come back from Pakistan and Iran. 


\subsection{Raj Village, Pusht-e-Rud District}

\section{Description}

The village is relatively close to Farah City on the opposite bank of the Farah Rud river. It suffers from being the last village to receive water from an access canal leading to the river and doesn't have enough water from the river to grow much more than barley. It has, therefore, concentrated on what it can grow by drawing on underground water through the use of water pumps. Grape production for sale is a major element in the local economy.

CHA were seeking to encourage greater diversification through the introduction of kitchen gardens in some homes and also through demonstration plots. In addition, they have organised a seed multiplication programme and undertaken repair work to the access road. DACAAR have provided drinking water wells.

The visit was facilitated by CHA.

Villagers' testimony

The population of this village is about 15,000. Before the war, it was about 5,000.

We farm about 35,000 jeribs at present, which is about the same as before the war. We farm this on a three yearly cycle, that is 12,000 jeribs per year. We survive through cultivation and livestock. Most people know how to weave but they don't know how to choose the right colours, etc. We therefore don't make carpets. There are about 2,000 young people living in Iran, and about 500 families. These are families which stayed on when the rest came back in 1992. Most are in Zahedan, Yazd and Kerman and they don't send any money back.

We grow wheat, barley and grapes. We don't have enough water to cultivate anything else; if we had water, we could cultivate melon or water melon, but the water we have isn't even enough for our grape gardens. About $90 \%$ of the families here have grape gardens. We grow more barley than wheat. It is about two-thirds barley and one third wheat. Other villages take water from the river before it reaches us so it is easier to grow barley than wheat. Before the war, we grew the same crops.

We have some cows and sheep. About 20 or 30 families have herds of sheep; other families have between one and four cows each. We had more livestock before the war.

We also had a karez before the war, which about 1,000 families were using, but now it is more than half destroyed. It would need a lot of work to get it functioning again. The wells at the beginning of the karez are in reasonable condition. We have sent a letter several times to the Governor of Farah about it and also asked CHA, but nothing has happened yet. If the karez was repaired we could grow corn, cotton and vegetables as well as water melon. We get some irrigation water from the wells, using water pumps, as the water table is quite high. This is good for gardens, but not suitable for wheat. Before the war, we had only two sources - the karez and the river - but now we have the additional source of wells with water pumps.

We sell grapes and raisins in the centre of Farah. Sometimes people come from Kandahar and buy 
them for export to Pakistan. Before the war, we also sold grapes, anab, and soft wool. It used to take us fifty minutes to get to Farah city by car, but since CHA have improved the road, it takes about half an hour. However, the main benefit from the work has been that a lot of fruit used to be damaged because the road was so bumpy.

We have two tractors, which are privately owned but also hired out. Before the war, we obtained tractors from the Agricultural Bank. They were Ferguson tractors from England; we were able to get these on credit. We had about five tractors.

We have no orchards. We didn't have any before the war. There wasn't enough water. Grapes and anab have a good resistance to water shortage. We have very few vegetable gardens, which is the same as before the war. There is no double cropping. We plant after the rains, even as late as March, and then we harvest in May.

Before the war, we received help with improved seed, fertilizer and pesticides from the Government, but the Government doesn't help now. A few families get help from CHA, so that they can test out and multiply improved seed or to demonstrate new varieties of crop.

About 500 families don't have their own land. Some of these go to Iran, whilst others work on other people's gardens or land as share-croppers. They receive about $25 \%$ of the harvest. About $50 \%$ of landowners have to do additional work for others; some of these are share-croppers. Some work as daily labourers in gardens, repairing walls or ploughing for grape bushes. Very few people were working in Iran before the war - maybe five per cent of the village population.

To improve the situation, the main things we need are water pumps, karez cleaning and a new school. This last is very important, as at the moment all the children are illiterate. We would be happy to have girls in school if one was opened and if the Taleban allowed it. Girls normally attend the mosque until they are ten. They learn some Koran and Persian poetry.

The head intake of the river is also a problem. In addition, the canal which brings water from the river needs cleaning. We would also like to have greater access to tractors, with or without credit, improved seed, fertilizer and pesticides. A clinic would also be a great help. If an agency was to give us a clinic, we would provide the land free of rent. We need a clinic for emergencies and also for poor people who cannot get to the city. We would also be able to help with the cleaning of the karez if an outside organization provided assistance.

At the beginning of the war, only ten families remained in the village. The rest went to Iran - to Shamsabad, and Zabul or Zahedan. The PDPA were killing people in the area, and there was heavy bombing by Soviet forces which killed 48 people in one particular attack. We used to run from our houses and hide in streams. A lot of young people were killed.

After we had gone to Iran, some of us used to come back into Afghanistan to fight as Mujahidin. We would do this for three months at a time and then have three months back in Iran.

After the fall of the Najibullah Government in April 1992, most of us came back gradually over a year; those who came early didn't get any assistance, whereas those who came later did. Most people from this village were not given anything. 
We survived for the first year on what we had saved from Iran, but we faced a lot of difficulties. We had to clean the canal which brought water from the river, since it was badly damaged. We did most of the work ourselves, although CHA helped us for two weeks at the end. We used a system, which goes back a long time, of each family or village contributing labour for public works. CHA gave us a small amount of wheat, but they didn't do anything of a technical nature.

When we came back from Iran, we also had nowhere to live, and there was no seed for cultivating, so we were facing difficulties from every side. We bought seed from the bazaar and some people brought some from Iran, but it was not improved seed, and we had very poor fertilizer. Most of us repaired our homes ourselves, without help from outside. CHA had a small shelter programme which helped 20 families. They were mostly poor people, and widows, so it was especially important for them. It bought their lives. We started planting in 1992. We managed to cultivate about half the land at that time.

CHA has helped us with road repair, with improved seed, and with the kitchen gardens introduced into some homes. DACAAR has provided wells for drinking water, with water pumps. There are eight in the village.

In Daoud's time and before, we were always forgotten because we had nobody with influence in the Government from the village. To get improved seed, we used to go to the Agricultural Bank, which was not too difficult, because they had professional people there, and we could also get credit. If a farmer wanted to develop a garden or dig a well, the Government would provide credit. The Government also gave oil and sugar.

The road which CHA has repaired was originally built by the Government. When we wanted to get the repair work done, we went to the CHA office in Farah, since we had heard about CHA's work from other villages. There were no other organisations, and we heard that CHA was able to give assistance. We met CHA three times before they started work. There wasn't much debate about what kind of surface to have. If it had been our choice, we would have had the road asphalted, but there was only gravel on offer. We just told CHA about our problems with the road and they got on with it. People from the village helped with levelling the road and CHA then surfaced it. 


\subsection{Denau Village, Khak-e-Safid District}

\section{Description}

Khak-e-Safid means "white earth" and is aptly named. The cultivated areas of the villages are surrounded by a desert of white cracked soil.

The District is to the north of the relatively fertile Pusht-e-Rud and Farah Districts and separated from them by an area of desert. Further north is a 70 kilometre stretch of increasingly stony desert extending up to Shindand.

CHA has worked quite intensively in the village and the people from the village have worked hard to restore the irrigation system. Although there is potential to further increase the cultivated area, primarily through the use of water pumps, the major work has been done.

The visit was facilitated by CHA.

Villagers' testimony

This village has approximately 200 families, which is about 1,200 people. There were about 600 - 700 before the war, but when we emigrated, the numbers increased. There the health situation was better than it is here and there were more vaccinations. Since we returned from Iran, we have had access to an organised vaccination programme here. However, the health provision is not as good as it was in Iran. There are fewer doctors but this does not affect us much. With the vaccination programme, we do not often get ill.

We cultivate on a three yearly cycle: about 1,000 jeribs each year out of a total of 3,000 jeribs. This is the same as before the war, but then we were cultivating on a four or five yearly cycle. With a smaller population then, it wasn't necessary to grow as much. During the first year after our return, we cultivated 500-600. jeribs.

About four or five families stayed during the war. The rest went to Iran. Most of our income now is from agriculture. Some of us have livestock. Other sources of income are not significant. For example, most people know how to weave, but only a handful make carpets. From each family, there are between two and four people working in Iran. They are usually aged 15-30, but if there are no young people in a family, then people up to the age of 45 go to Iran.

We cultivate wheat, barley and alfalfa; $95 \%$ of our crop is wheat. We grow less barley than before. We also grow vegetables through kitchen gardening. The larger landowners have alfalfa and grazing for livestock. Before the war, it was much the same, except that alfalfa was not grown then. Very few people worked in Iran before the war.

Most people have goats, and some have cows and sheep, but we had more animals before the war. We may be able to recoup our livestock numbers over five to ten years, but it is easier to get work in Iran than to live from livestock. If it became difficult to get work in Iran, we would use the extra labour to work on the land. 
However, water is a problem. We could irrigate far more if we had more labour and more pumps, and we would benefit from an enlarged irrigation system. If we could expand our irrigated areas, it would not be necessary for people to go to Iran. We are irrigating land from the Farah Rud but it doesn't have enough water for the whole year; the village is 30 kilometres from the river and the water comes along a canal. There are seven villages which draw water from the canal and each village provides 35-40 workers to undertake repairs to the canal twice a year. Other villages in the district have karezes and are not partners in the canal.

We harvest in the spring before the water in the canal dries up. After that we have no work until we plant in the autumn. When we plant, we need water. If the rains have come and there is water in the river, we can plant in the autumn. Otherwise, we have to wait until the winter. To further improve our irrigation, we need more deep wells with water pumps. We have the same irrigation system now as we did before the war.

We do not sell any agricultural products to other villages, just within the village, but sometimes we buy from other villages. We didn't sell outside the village even before the war.

We are working much harder than before. We have four tractors in the village, which are owned by particular farmers and rented out. When we plough ten jeribs, we get 500 kilogrammes of wheat, which gives us, after threshing, 30 kilogrammes of the end product. It is much better with a tractor. Before the war we didn't have any tractors. We only used oxen.

We don't have any orchards, nor did we before the war. Only a minority of people have vegetable gardens - those with water pumps. We didn't grow vegetables before the war. We bought them in the bazaar. CHA has provided vegetable seeds and fertilizer to encourage farmers to grow them. We know much more about vegetable growing now than we did before the war. This is the result of CHA's encouragement.

Our biggest problem is the shortage of water. In addition, improved seed, pesticides, herbicides and fertilizer are not available. We have to trust in God as there is no office to help with pests. We used to get help from the Government before the war. About a quarter of the families in the village have no land. Some of these go to Iran; some work for other farmers as share-croppers with a $25 \%$ share. Land ownership is much the same as before the war. There is only occasional daily labouring work relating to cultivation. Most labouring work is in construction and repair. Vulnerable families are helped through charitable giving.

Most of us left because of the Soviet presence and because of the fighting which broke out with the PDPA regime. The village was bombed, but only a few houses were destroyed. When we came back, however, many houses were in a very bad state due to neglect.

In Iran, we were living near Birjand. We returned to Afghanistan gradually over a five month period in 1992/93. We all came back. Most people did not get any assistance at the border - only those who came later, and they got the full ration. The people working in Iran are sending money; they usually return every six months and stay for a month before going back. Some of those in Iran work particularly hard and so are able to send more money back than others.

When we first returned, the major problem we faced was the damage to our houses; we lived in tents provided by the Iranian Government and UNHCR. We have worked on the houses ourselves, 
but it has taken us two or three years, already, and, still, some rooms in each house are awaiting repair. The land was also in a bad condition, largely because of flood damage. We had to remove the rough grass which covered it and we were only able to plant on a small area of land at first. The area of land cultivated has increased over several years, and now the situation is reasonably good.

CHA have done a lot in this village. They have cleared karezes, which has benefited nearby villages as well as this one. They have provided shallow wells for drinking water and given wheat, oil and beans to those who dug them. They have established vaccination programmes. Some assistance has also been given to people rebuilding their homes. CHA has also helped with kitchen gardening. They have demonstrated how to grow certain plants.

The CHA programme has been of benefit because it is now possible to get healthy water from the wells. It is good to have our children vaccinated. The kitchen garden programme is also useful. Now, our priority is to have improved seed, fertilizer, tractors, deep wells and water pumps. Also, there is no school here. In Birjand, we had a Government-supported education system. Education was available to our children up to the end of primary school. Even the older children would attend primary school, as well as working. In Iran, only the boys were educated. In accordance with our culture, we didn't allow our girls to be educated even though the Iranian Government encouraged us to send them to school.

MERLIN and CHA are working together in the clinic here. However, it doesn't have a doctor. There are only a few drugs and a few injections. If one of the children is ill, we have to go to private doctors or to pharmacies in Farah city. We use the clinic if we get headaches or diarrhoea, but otherwise we go to the city. However, we do use the clinic if there is an emergency. We have asked MERLIN to send a doctor here once a week from the city, but nothing has happened. They have sent a foreign woman doctor, but she only examines pregnant women. We recognise that doctors have a tendency to over-prescribe and we have to pay a lot for drugs. The doctors keep the pharmacies in business. 
Objectives

(a) to establish, through interviews with farmers in Farah Province, including those who have returned after a period of displacement, the likelihood and feasability of durable socioeconomic re-integration in the future.

\section{Questions used as basis for semi-structured interviews}

Questions aimed at setting the scene

1. How many people are living in the village, approximately? How many were here before the war?

2. How many jeribs of land are farmed, approximately? How many were farmed before the war?

3. How are you surviving? What resources are coming in? What resources were coming in before the war?

4. What crops are grown? What crops were grown before the war and what changes have there been in-between?

5. What kinds of livestock do you have? What kinds of livestock did you have before the war and what changes have there been in-between?

6. What systems of irrigation do you use? Which is the most important? What are the problems with each of them? What action has been taken so far to improve the situation?. What still needs to be done?

7. Do you sell agricultural produce? What and how much? Is it different now from before and during the war? How long does it take to travel to the nearest bazaar? What is the name of it? How long did it take before the war? Has any work been done to improve the road? Who did the work?

8. How many tractors are there in the village? Who owns them?

9. How many orchards are there in the village? What is grown in them? How many were there before the war?

10. Are there any vegetable gardens?

11. When do you plant? When do you harvest? What are the main problems you face in trying to grow the various crops? (climatic, pests, flooding) 
12. Do you have summer crops and winter crops on the same land? Which crops are they? What changes have there been?

13. Do you receive any help with improved seed and/or fertiliser? Were farmers given support before the war? What assistance did the government give to support both crops and livestock?

14. How many families are supported by people who own their own land? Do any of these families have to do additional work, for example as labourers on other people's land? Were some farmers self-sufficient before the war?

15. How many families are supported by sharecroppers? Do any of these families have to do additional work, for example as labourers on other people's land?

16. How many families are supported by people who work exclusivly as labourers on other people's land?

17. Are there any families which do not have an adult male providing support? How are they surviving?

Questions relating to pre-war period

18. Is this where you were living before the war?

19. How did you survive then?

20. How many families were able to survive exclusively from the land?

21. How many families had to depend, at least in part, on daily labouring or on some family members working in Iran?

22. How well off were people before the war. Did it vary from area to area? Where were the richest and the poorest parts? How far off is the level of prosperity now from that pertaining before the war? How could the village get back to pre-war levels or move forward to an improved situation. What options exist?

Questions aimed at establishing whether people remained in their village throughout the war.

23. When the Soviet forces entered Afghanistan, did you remain in the village?

24. (IF NOT) Where did you go?

25. When did you leave?

26. What were the circumstances that led you to leave?

27. How many of the family left with you?

28. Where did they go? What happened to them? How did they survive? 
29. (IF THEY WENT TO IRAN) When you returned to Afghanistan, did you get any help at the border?

30. Did you know about the UNHCR assistance of cash and wheat?

31. If so, did this make any difference to your decision to go back?

32. What were the main factors which made you decide to come back to Afghanistan?

33. What had stopped you going back earlier?

34. Do you think it would have made any difference if the assistance package given at the border had been more generous?

35. How did you use it?

36. Do you think it is more useful to have an assistance package at the border or for outside assistance to be given for the reconstruction of your village?

37. Had you been back to your village since you first left? How often?

38. Did some family members return earlier than others? Why was that?

39. When did you finally return to your village?

40. (IF THEY STAYED IN THE VILLAGE) Did everyone stay here or did some people leave. Where did they go? How did people survive during the Soviet period, and during the initial years afterwards?

Questions relating to relatives elswhere

41. Are any of your family working outside Afghanistan?

42. What are they doing?

43. Are they sending you any money?

44. Do you think they will stay where they are?

45. What would make them decide to come back?

46. Are there any members of your family living in other parts of Afghanistan?

47. Where are they living?

48. How are they surviving? 
Questions relating to the immediate post-retum period

49. What were the major difficulties you faced when you first came back?

50. What was the first thing that you did - and the next etc?

51. How did you survive during the first year or so?

52. Did people help each other during this initial period? If so, what form did it take and what difference did it make? Was it from people who had been here through the war or from returnees?

53. Did you get any help from outside organisations? If yes, what help did you get and from whom? When was the help received? Did it make a difference, in the short and in the long term and, if so, what? If longer term help has been given, what form has it taken and what impact do you think it will have?

54. Did other villages get any help and, if so, what was it and by whom was it given? What difference did it make to them and to the village?

55. Was the village consulted about the assistance and, if so, how? If not, what do you think about that? If yes, was the consultation carried out in a good way and should others follow a similar process? Could it have been improved? How are decisions taken in the village?

56. What did you find was the most helpful thing of all on your return? Which was the most unhelpful?

57. Do you know about the work of MERLIN/ADA/CHA? Has their work affected you or members of your family, or other people and, if so, how? What do you think of MERLIN/CHA/ADA?

58. Looking back, what kind of help would have been most useful when you first returned? What are the main problems that you face now? What kind of help would be most useful now?

59. (IF THEY WERE NOT HELPED) Did other villages get any help and, if so, what was it and by whom was it given? What difference did it make to them and to the village? 
Table 1 Population/Jerib and landless: 1997

$\begin{array}{lcccc} & \text { Population } & \begin{array}{l}\text { Jeribs } \\ \text { farmed } \\ \text { annually }\end{array} & \begin{array}{c}\text { Population/ } \\ \text { jerib }\end{array} & \begin{array}{c}\text { Landless } \\ \text { as } \% \text { of } \\ \text { total }\end{array} \\ \text { Massaw } & 8,000 & 9,720 & 1.22 & 4 \% \\ \text { Anar Dara } & 5,600 & 5,000 & 0.89 & 33 \% \\ \text { Bakwa } & 4,550 & 1,000 & 0.22 & 85 \% \\ \text { Pushtuku } & 3,500 & 750 & 0.21 & 50 \% \\ \text { Shabiku } & 1,120 & 150 & 0.13 & 25 \% \\ \text { Farah } & 3,500 & 1,350 & 0.40 & 50 \% \\ \text { Bala Balouk } & 8,000 & 875 & 0.11 & 5 \% \\ \text { Raj } & 15,000 & 11,666 & 0.77 & 27 \% \\ \text { Khak-e-Safid } & 1,200 & 1,000 & 0.83 & 25 \%\end{array}$

Table 2 Population/Jerib: 1977

\begin{tabular}{lrrr} 
& Population & \multicolumn{1}{l}{$\begin{array}{l}\text { Jeribs } \\
\text { farmed } \\
\text { annually }\end{array}$} & $\begin{array}{l}\text { Population/ } \\
\text { jerib }\end{array}$ \\
Massaw & 4,000 & 10,050 & 2.51 \\
Anar Dara & 3,300 & 5,000 & 1.51 \\
Bakwa & 3,500 & 1,000 & 0.29 \\
Pushtuku & 2,240 & 1,500 & 0.67 \\
Shabiku & 700 & 400 & 0.57 \\
Farah & 4,900 & 1,400 & 0.28 \\
Bala Balouk & 24,000 & 2,000 & 0.08 \\
Raj & 5,000 & 11,666 & 2.33 \\
Khak-e-Safid & 650 & 666 & 1.02 \\
return and reconstruction & &
\end{tabular}




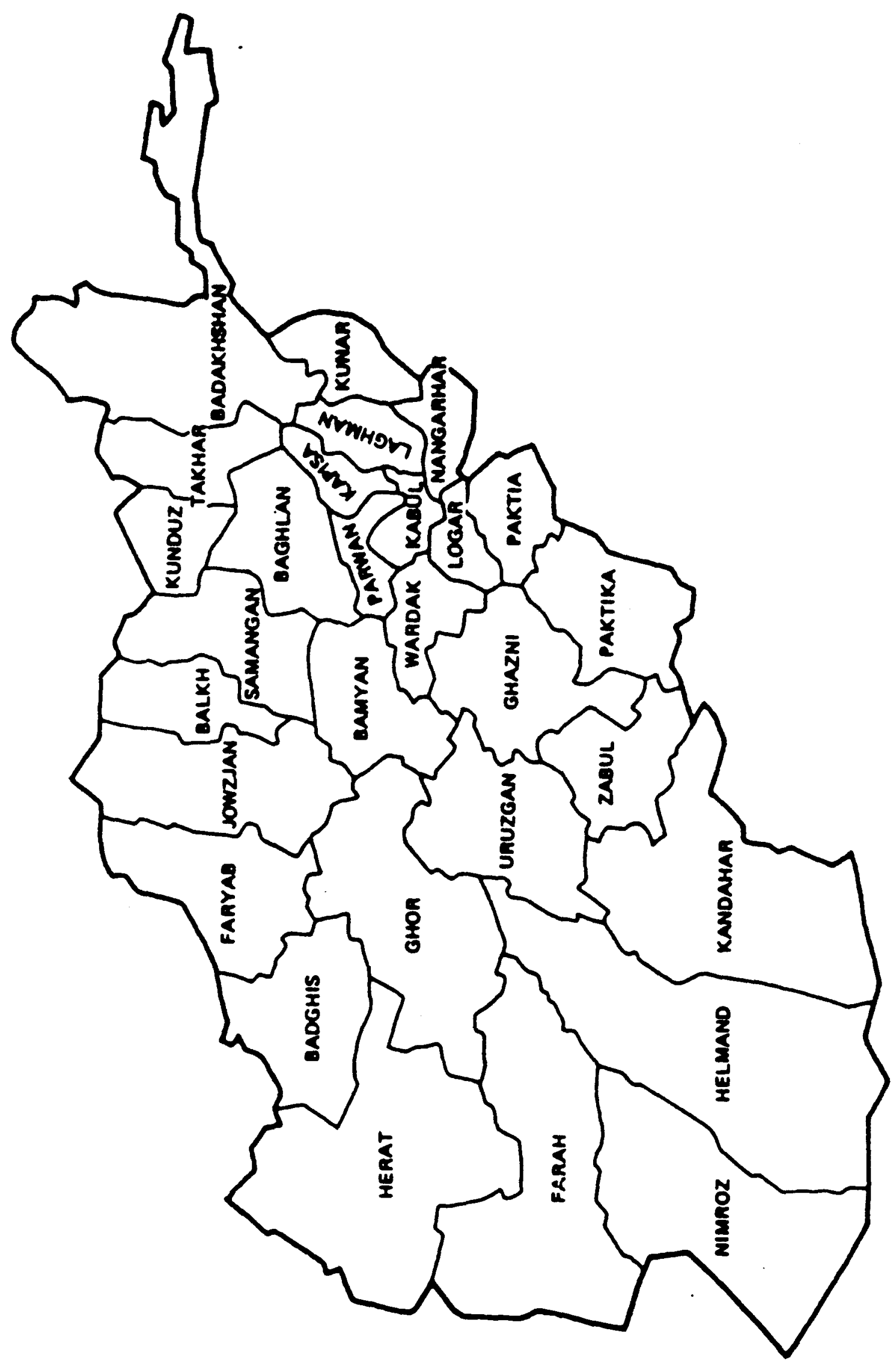




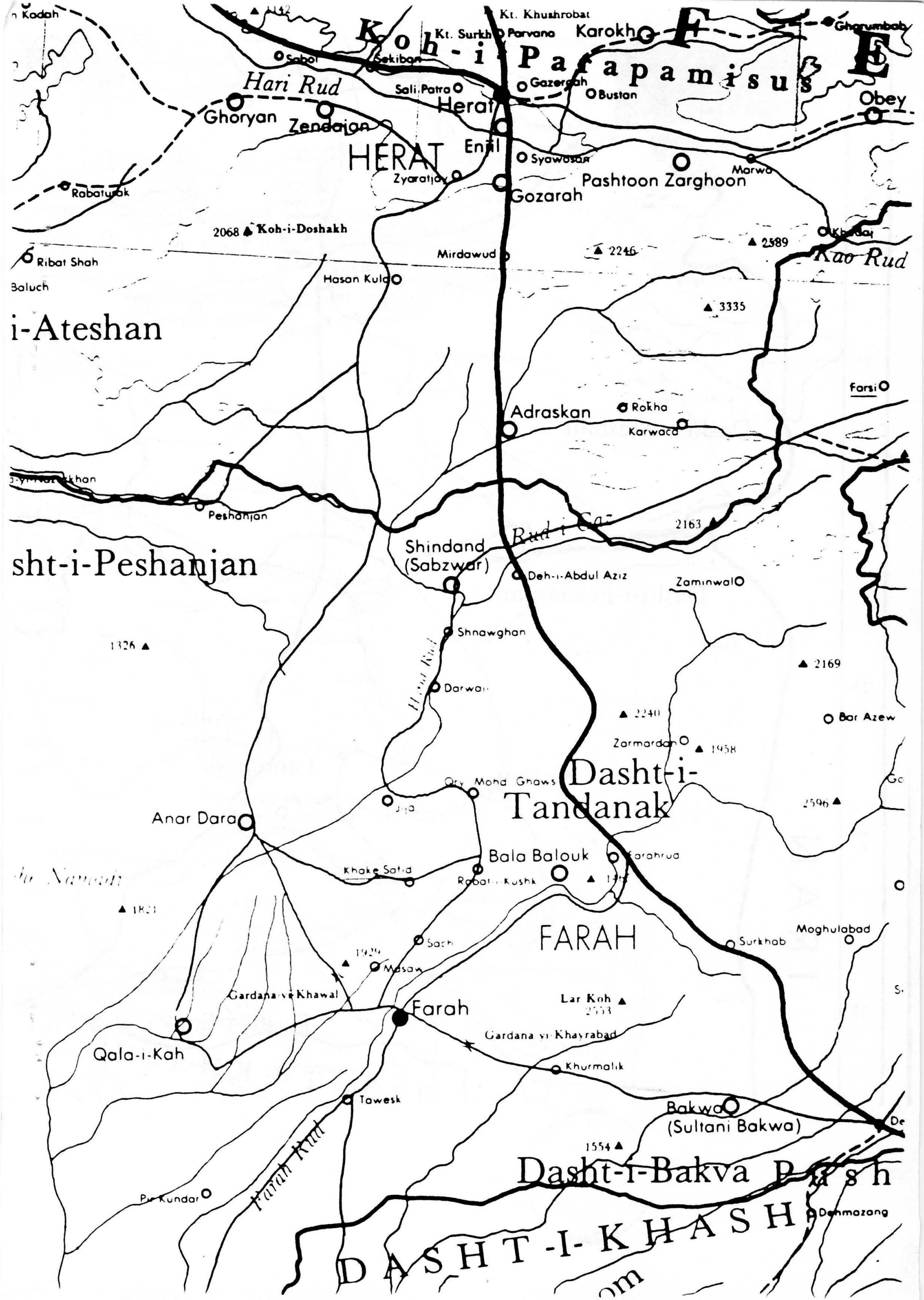


